\title{
TINGKAT KINERJA DOSEN TERHADAP PEMENUHAN STANDAR KOMPETENSI UNTUK MEMENUHI MUTU PELAYANAN AKADEMIK MAHASISWA JURUSAN JPMIPA FKIP UM-MATARAM
}

\author{
Oleh: \\ Khairil Anwar, S.Pd.,M.Pd.Si (Anggota) \\ M. Firman Ramadhan, S.Pd.,M.Pd.Si (Ketua) \\ Islahudin, S.Pd.,M.PFis (Anggota) \\ RINGKASAN
}

Kinerja staf pengajar (Dosen) dalam menjalankan tugas dan pekerjaannya tidak terlepas dari motivasi yang ada dalam diri masing-masing, maupun dari mahasiswa yang secara tidak langsung memberikan tantangan tersendiri untuk selalu mendalami dan mengasai bidang ilmu pengetahuannya. Demikian juga sebaliknya, mahasiswa pun akan termotivasi belajarnya terhadap kinerja dosen yang berkwalitas serta daya dukung sarana prasarana yang memadai. Hasil observasi terhadap mahasiswa jurusan PMIPA FKIP UMMataram, secara garis besar kompetensi sumber daya manusia belum mencapai sasaran yang diharapkan. Hal ini dikarenakan belum adanya peran, motivasi, atau kinerja dosen dan mahasiswa secara maksimal dalam usaha-usaha pencapaian tujuan yang ditetapkan instistusi sehingga perlu dilakukan evaluasi kinerja dosen yang mengajar pada masingmasing program studi di jurusan PMIPA agar pelayanan terhadap mahasiswa dapat lebih ditingkatkan. Oleh karena itu untuk mengetahui secara ril kondisi kinerja dosen JPMIPA maka dilakukan penelitian tentang "Tingkat Kinerja Dosen Terhadap Pemenuhan Standar Kompetensi untuk Memenuhi Mutu Pelayanan Akademik Mahasiswa Jurusan JPMIPA FKIP UM-Mataram tahun akademik 2012-2013.

Penelitian ini merupakan penelitian deskriptif dimana data yang dikumpulkan berupa angket kuesioner evaluasi kinerja dosen sebagai bentuk mutu pelayanan akademik mahasiswa. Selanjutnya dianalisis menggunakan skor skala 1-5, yang sebelumnya telah dianalisis standar validitas dan reliebilitasnya. Aspek yang dinilai terdiri dari empat kompetensi yang masing-masing mengandung pertanyaan. Adapun komposisi daftar pertanyaan adalah 9 daftar pertanyaan tentang kompetensi Pedagogik, delapan pertanyaan untuk kompetensi professional, enam pertanyaan untuk kompetensi kepribadian, dan lima daftar pertanyaan utnuk kompetensi sosial. Untuk menyatakan besar kecilnya kwalitas kinerja dosen, ditentukan dengan rumus rating scala, sehingga dapat diketahui tingkat kinerja dosen dalam pemenuhan standar kompetensi.

Dari hasil penyebaran angket yang berhasil dikumpulkan diperoleh jumlah total responden sebanyak 85 orang. Biodata pada lembaran angket hanya diperkenankan mengisi nama matakuliah dan nama dosen yang akan dievaluasi kinerjanya. Berdasarkan hasil analisis data, menunjukkan bahwa kinerja masing-masing dosen pengampu mata kuliah di jurusan PMIPA FKIP UM-Mataram pada tahun akademik 2012-2013 dalam standar kerja yang baik, dengan nilai rata-rata prosentase 70,55. Sedangkan secara umum kinerja dosen telah memenuhi empat aspek standar kompetensi 77,54\%.

Kata Kunci: Kinerja, Kwalitas, Kompetensi akademik 


\section{BAB I \\ PENDAHULUAN}

\subsection{Latar Belakang}

Dalam Undang-undang nomor 14 Tahun 2005, pasal 1 ayat 2, mengatakan bahwa Dosen adalah pendidik profesional dan ilmuwan dengan tugas utama mentransformasikan, mengembangkan, dan menyebarluaskan ilmu pengetahuan, teknologi, dan seni melalui pendidikan, penelitian, dan pengabdian kepada masyarakat. Sehingga berkaitan dengan amanat undang-undang tersebut seorang dosen harus memiliki standar-standar kompetensi diantaranya kompetensi pedagogik, kompetensi professional, kompetensi kepribadian, hingga kompetensi sosial. Komunikatif, serta hubungan yang baik dengan semua pelaku akademik khususnya mahasiswa, akan memberi hasil yang baik pula terhadap proses, maupun evaluasi pelaksanaan kegiatan akademik.

Kinerja staf pengajar (Dosen) dalam menjalankan tugas dan pekerjaannya tidak terlepas dari motivasi yang ada dalam diri masing-masing, maupun dari mahasiswa yang secara tidak langsung memberikan tantangan tersendiri untuk selalu mendalami dan mengasai bidang ilmu pengetahuannya. Demikian juga sebaliknya, mahasiswa pun akan termotivasi belajarnya terhadap kinerja dosen yang berkwalitas serta daya dukung sarana prasarana yang memadai. Motivasi tersebut akan terlihat sebagai bentuk aktivitas-aktivitas yang dilakukan dalam melaksanakan tugas dan pekerjaan dan fungsi masing-masing, serta hasil evaluasi akademik yang diperoleh.

Untuk mewujudkan tujuan di atas sangat diperlukan peran dosen sebagai pengajar sekaligus sebagai pendidik serta peran Universitas sebagai lembaga pendidikan. Dosen memiliki peran yang sangat penting dalam menentukan kuantitas dan kwalitas pengajaran yang dilaksanakannya. Oleh sebab itu, dosen harus memikirkan dan membuat perencanaan secara seksama dalam meningkatkan kesempatan belajar bagi mahasiswa dan memperbaiki kwalitas mengajar kinerjanya.

Jurusan Pendidikan Matematika dan Ilmu Pengetahuan Alam (PMIPA) Fakultas Keguruan dan Ilmu Pendidikan (FKIP) Universitas Muhammadiyah Mataram (UM-Mataram) terbagi dalam dua program studi, yaitu program studi pendidikan fisika dan program studi pendidikan matematika. 
Berdasarkan Observasi non-sistematis yang dilakukan oleh peneliti pada masing-masing program studi masih terlihat sekitar 20\%-40\% dari jumlah mahasiswa pada tiap-tiap kelas yang terlihat aktif dalam kegiatan belajar mengajar. Hal ini terlihat dari kurangnya motivasi mahasiswa dalam bertanya, berdiskusi, beragumen, maupun dalam mengerjakan latihan soal yang diberikan. Hal ini disebabkan karena mahasiswa tidak tertarik dengan mata kuliah yang diberikan yang mana hal ini berhubungan langsung dengan kinerja pengajar (Dosen) sehingga mahasiswa kurang termotivasi dalam usaha menguasai materi yang disampaikan. Berdasarkan kenyataan di atas, maka peneliti melakukan evaluasi kinerja dosen yang mengajar pada masing-masing program studi di jurusan PMIPA agar pelayanan terhadap mahasiswa dapat lebih ditingkatkan.

\section{BAB II \\ TUJUAN DAN MANFAAT PENELITIAN}

\subsection{Tujuan Penelitian}

Adapun tujuan yang ingin dicapai dalam penelitian ini adalah mengetahui tingkat kinerja dosen dalam berbagai aspek kompetensi sebagai pengajar, yang merupakan salah satu faktor yang sangat berpengaruh terhadap motivasi, hasil, dan prestasi akademik mahasiswa sebagai bentuk pelayanan di jurusan PMIPA FKIP UM-Mataram.

\subsection{Manfaat Penelitian}

Mutu pendidikan tinggi ditentukan juga oleh sumber daya manusia selain oleh organisasi yang sehat dan manajemen yang efektif. Komitmen pimpinan dan staf mutlak diperlukan. Oleh karena itu, bentuk penelitian ini merupakan salah satu valuasi kinerja Jurusan atau Program Studi (PS) dalam berbagai aspek, sehingga dapat diketahui tingkat standar mutu yang telah dicapai oleh masing-masing dosen. Sehingga dapat menjadi acuan dalam usaha mengembangkan program studi di jurusan JPMIPA ataupun jurusan lainnya dalam meningkatkan kinerja dosen, peningkatan pelayanan jurusan, dan peningkatan mutu serta kwalitas mahasiswa jurusan di lingkungan FKIP Universitas Muhammadiyah Mataram, 
khususnya pada jurusan PMIPA sehingga dapat menjamin mutu akademik yang melingkupi berbagai aspek, diantaranya:

1. Kurikulum Program Studi

2. Sumber Daya Manusia (dosen dan tenaga penunjang)

3. Mahasiswa dan Kompetensi Lulusan

4. Proses Belajar Mengajar

5. Sarana dan Prasarana Akademik

6. Suasana Akademik

7. Penelitian dan Publikasi

8. Pengabdian kepada Masyarakat

9. Manajemen Akademik

\section{BAB III \\ TINJAUAN PUSTAKA}

\subsection{Landasan Teori}

\subsubsection{Evaluasi pendidikan}

Istilah evaluasi berasal dari bahasa inggris yaitu "Evaluation”. Dalam buku Essential of Educational Evaluation karangan Edwind Wand dan Gerald W. Brown dikatakan bahwa:

Evaluasi adalah suatu tindakan atau suatu proses untuk menentukan nilai daripada sesuatu. Seseuai dengan pendapat tersebut maka evaluasi pendidikan dapat diartikan sebagai suatu tindakan atau suatu proses untuk menentukan nilai segala sesuatu dalam dunia pendidikan atau segala sesuatu yang ada hubungannya dengan dunia pendidikan (Nurkencana dan Sumartana, 1991).

Evaluasi meliputi pengukuran dan penilaian, pengukuran adalah membandingkan sesuatu dengan satu ukuran sedangkan penilaian adalah mengambil suatu keputusan terhadap sesuatu dengan ukuran baik buruk. Di dalam istilah asingnya pengukuran adalah measurement sedangkan penilaian adalah evaluation. Dari kata evaluation inilah diperoleh kata Indonesia evaluasi yang berarti menilai atau tetapi dilakukan dengan mengukur terlebih dahulu (Arikunto, 2011). 


\subsubsection{Psikologi pembelajaran}

Menurut mahasiswa dalam suatu penelitian, fungsi kuliah ialah mengintroduksi mata kuliah yang baru dan menunjukkan hubungannya dengan bidang studi lainnya, memberi keterangan tentang perkembangan baru dalam ilmu itu, yang belum dimuat dalam buku perkuliahan, dan membuka kesempatan untuk mengemukakan masalah-masalah serta cara-cara untuk mencari pemecahannya. Para pengajar menganggap bahwa kuliah dapat berfungsi untuk mendorong mahasiswa untuk membaca bahan lain. Namun sejumlah mahasiswa semata-mata hanya mempelajari catatan perkuliahan sebagai bahan untuk ujian dan sebagian besar dari mahasiswa memperoleh pengetahuan mereka terutama dari perkuliahan (Nasution, 2010).

\subsubsection{Pengertian Kinerja}

Istilah kinerja mengandung berbagai macam pengertian. Kinerja dapat ditafsirkan sebagai “arti penting suatu pekerjaan”; “tingkat keterampilan yang diperlukan”; "kemajuan dan tingkat penyelesaian” dari suatu pekerjaan (Panggabean, 2002). Di lain pihak menurut Simamora (2003) kinerja karyawan adalah tingkat pencapaian pekerjaan oleh karyawan.

Sehubungan dengan kebutuhan akan keberhasilan, Panggabean (2002) mengemukakan achievement motivation theory, yang berpendapat bahwa orang yang mempunyai kebutuhan untuk berhasil atau mencapai suatu keinginan memiliki beberapa ciri, yaitu:

a. Menentukan tujuan yang tidak terlalu rendah, tetapi tujuan yang bisa memberi tantangan untuk dapat dikerjakan dengan baik.

b. Menentukan tujuan yang secara pribadi dapat diketahui bahwa hasilnya dapat dikuasai bila mereka mengerjakan sendiri.

c. Senang kepada pekerjaannya, dan mempunyai kepentingan dengan keberhasilannya sendiri.

d. Suka bekerja dalam bidang pekerjaan yang bisa memberikan gambaran tentang pekerjaan yang dilakukan. 


\subsubsection{Tolok Ukur Kinerja}

Mutu kerja karyawan (Dosen) secara langsung mempengaruhi kinerja perguruan tinggi. Guna mendapatkan kontribusi yang optimal, manajemen harus memahami secara mendalam strategi untuk mengelola, mengukur dan meningkatkan kinerja, yang dimulai dengan terlebih dahulu menentukan tolok ukur kinerja. Ada beberapa syarat tolok ukur kinerja yang baik (Bestira, 1988), yaitu haruslah mampu diukur dengan cara yang dapat dipercaya. Konsep keandalan pengukuran mempunyai dua komponen; stabilitas dan konsistensi. Stabilitas menyiratkan bahwa pengukuran yang dilakukan pada waktu yang berbeda haruslah mencapai hasil yang kira-kira serupa. Konsistensi menyiratkan bahwa pengukuran kriteria yang dilaksanakan dengan menggunakan metode yang berbeda atau orang yang berbeda haruslah mencapai hasil yang kira-kira sama.

\subsubsection{Aspek-aspek Pengukuran Kinerja}

Untuk mengetahui tingkat keberhasilan kinerja pegawai, maka harus ada pengukuran kinerja. Pengukuran kinerja digunakan untuk penilaian atas keberhasilan atau kegagalan pelaksanaan kegiatan/ program/kebijaksanaan sesuai dengan sasaran dan tujuan yang telah ditetapkan dalam rangka mewujudkan misi dan visi organisasi. Pengukuran kinerja tersebut mencakup indikator-indikator pencapaian kinerja. Sehubungan dengan hal tersebut, maka penulis mencoba memaparkan berbagai pendapat para ahli tentang indikator kinerja.

Berdasarkan pendapat Gibson bahwa kinerja diukur berdasarkan waktu memberi kesan mengesampingkan berbagai kemungkinan factor-faktor lain yang merupakan indikator dan kinerja itu. Kemudian Cascio (dalam Gibson, et. al. (1992 : 45), mengatakan bahwa untuk mengetahui sejauHmana tingkat hasil pelaksanaan pekerjaan/kinerja karyawan sekiranya perlu dilakukan evaluasi dengan menguraikan beberapa hal yang berkaitan dengan penilain pekerjaan antara lain:

a. Kinerja menunjukkan kepada penyelesaian tugas yang dilakukan oleh karyawan. 
b. Penilaian kinerja adalah uraian sistematik dari kekuatan dan kelemahan berkenaan dengan pekerjaan seseorang atau kelompok.

c. Periode penilaian kinerja adalah rentang waktu dimana seseorang diamati prestasi kerjanya untuk membuat laporan formal.

Pendapat Cascio ini juga mengedepankan indikator waktu sebagai indikator pengukuran dan kinerja itu, jadi indikator lain kurang ditampilkan. Selanjutnya Jan Erik Lane (1995) menyatakan bahwa yang umum dianggap sebagai indikator kinerja antara lain adalah:
a. Responsivitas
b. Efisiensi
c. Kepentingan publik
d. Kepentingan privat
e. Fungsi-fungsi khusus

Sedangkan Simamora (2003) mengqngkapkan bahwa ada 3 (tiga) dasan perilaku yang akan dimasukkan dalam penilaian kinerja agar organisasi berfungsi secana efektif yaitu:

a. Memikat dan menahan sejumlah orang ke dalam organisasi dalam jangka waktu tertentu, sehingga organisasi meminimalkan perputaran karyawan.

b. Penyelesaian tugas yang terandalkan, tolok ukur minimal kualitas kinerja tercapai.

c. Perilaku inovasi dan spontan.

Menurut Robbins (1997) hakekat penilaian kinerja individu adalah hasil kerja yang optimal. Penilaian kinerja tersebut mencakup:
a. Kemampuan bekerjasama
b. Kualitas pekerjaan
c. Kemampuan teknis
d. Inisiatif

Disampaikan dalam seminar penelitian LEMLIT UM. Mataram / 2013. 
e. Semangat

f. Daya tahan/kehandalan

g. Kuantitas pekerjaan

Sehubungan dengan hal tersebut maka indikator kinerja yang digunakan dalam penelitian ini adalah 4 indikator kinerja yang meliputi Kompetensi Pedagogik, Kompetensi Profesional, Kompetensi kepribadian, dan kompetensi sosial.

\section{BAB IV \\ METODE PENELITIAN}

\subsection{Desain Penelitian}

Penelitian ini merupakan penelitian deskriptif yaitu penelitian yang dilakukan melalui nilai variabel mandiri, baik satu variabel atau lebih (independen) tanpa membuat perbandingan, atau menghubungkan antara variabel satu dengan variabel yang lain (Sugiyono, 2008). Dalam hal ini peneliti ingin meneliti kinerja dosen terhadap kepuasan mahasiswa program studi di jurusan PMIPA Universitas Muhammadiyah Mataram tahun akademik 2011/2012.

\subsection{Instrumen Penelitian}

Untuk mengetahui apakah angket tersebut sudah baik atau tidak, yakni dengan mencari validitas dan reliabilitas.

\section{Validitas}

Validitas digunakan untuk mengetahui apakah angket yang digunakan sudah tepat atau betul-betul menilai apa yang seharusnya dinilai. Analisis validitas dilakukan dengan menggunakan korelasi product moment dengan angka kasar (Arikunto, 2008):

Nilai $r_{\mathrm{xy}}$ selanjutnya dikonsultasikan pada tabel $r$ product moment pada tingkat kepercayaan 95\%. Kriteria adalah jika $r_{\mathrm{xy}}>r_{\text {tabel }}$ maka angket tersebut dikatakan valid, sebaliknya jika $r_{\mathrm{xy}}<r_{\text {tabel }}$ maka angket tersebut dikatakan tidak valid. 
2. Reliabilitas

Reliabilitas digunakan untuk mengetahui keajegan angket. Analisis reliabilitas dilakukan dengan menggunakan rumus Alpha (Arikunto, 2008).

$r_{11}=\left(\frac{k}{k-1}\right)\left(1-\frac{\sum \sigma_{b}^{2}}{\sum \sigma_{t}^{2}}\right)$

Keterangan:

$r_{11} \quad=$ reliabilitas instrumen

$k=$ banyak butir pertanyaan atau banyaknya soal

$\sum \sigma_{b}^{2}=$ jumlah varians butir item

$\sum \sigma_{t}^{2}=$ jumlah varians total

Sementara itu untuk mencari nilai varians digunakan Persamaan 3.3.

$\sigma^{2}=\frac{\sum X^{2}-\frac{\left(\sum X\right)^{2}}{N}}{N}$

Nilai $r_{11}$ selanjutnya dikonsultasikan pada tabel $r$ product moment pada tingkat kepercayaan 95\%. Kriterianya adalah jika $r_{11}>r_{\text {tabel }}$ maka angket tersebut dikatakan reliabel, sebaliknya jika $r_{11}<r_{\text {tabel }}$ maka angket tersebut dikatakan tidak reliabel.

\subsection{Teknik Pengumpulan Data dan analisis data}

Data yang dikumpulkan berupa angket evaluasi kinerja dosen. Evaluasi kinerja dosen diperoleh dengan cara memberikan angket kepada mahasiswa di setiap program studi pada jurusan PMIPA Universitas Muhammadiyah Mataram.

Data evaluasi kinerja dosen oleh mahasiswa berbentuk kuesioner, selanjutnya dianalisis secara deskriptif kualitatif dengan menggunakan skor skala 1 - 5 (5= sangat baik, 4= baik, 3= cukup, 2= tidak baik, 1= sangat tidak baik). Selanjutnya untuk mengetahui kinerja dosen dapat ditentukan dengan rating scale (Riduwan dan Sunarto, 2010):

Nilai $=\frac{\sum Y}{\left(\text { skor }(\text { tertinggi }) \times \sum i t e m\left(\sum \text { responden }\right)\right)}$ 


\section{BAB V \\ HASIL DAN PEMBAHASAN}

\subsection{Karakteristik Responden}

Karakteristik subjek penelitian tidak dapat ditentukan. Karena identitas tidak dianjurkan. Berdasarkan sebaran matakuliah dan jumlah respondennya terdiri dari 13 matakuliah dan 85 orang responden.

\subsection{Karakteristik Instrumen}

Data evaluasi kinerja dosen oleh mahasiswa berbentuk kuesioner, selanjutnya dianalisis secara deskriptif kualitatif dengan menggunakan skor skala 1 - 5. Aspek yang dinilai terdiri dari empat kompetensi yang masing-masing mengandung pertanyaan. Adapun komposisi daftar pertanyaan adalah 9 daftar pertanyaan tentang kompetensi Pedagogik, delapan pertanyaan untuk kompetensi professional, enam pertanyaan untuk kompetensi kepribadian, dan lima daftar pertanyaan utnuk kompetensi sosial.

\subsection{Deskripsi Instrumen Penelitian}

\subsubsection{Uji Validitas}

Dari hasil uji coba instrumen yang dilakukan pada 85 responden diperoleh hasil yang terlihat dalam Tabel 5.1,.

Tabel 5.1. Hasil Uji Validitas.

\begin{tabular}{clccc}
\hline $\boldsymbol{N}$ & \multicolumn{1}{c}{ Jenis Kompetensi } & $\begin{array}{c}\text { Jumlah } \\
\text { item } \\
\text { pertanyaan }\end{array}$ & Valid & $\begin{array}{c}\text { Tidak } \\
\text { Valid }\end{array}$ \\
\hline \multirow{2}{*}{85} & Kompetensi Pedagogik & 9 & 7 & 2 \\
Kompetensi Profesional & 8 & 7 & 1 \\
& Kompetensi & 6 & 6 & - \\
& Kepribadian & 5 & 5 & - \\
\hline
\end{tabular}

\subsubsection{Uji Reliabilitas}

Uji coba reliabilitas dilakukan pada semua item pertanyaan yang telah valid dengan menggunakan rumus Alpha, diperoleh semua item berstatus relabel. 


\subsection{Deskripsi Kinerja masing-masing Dosen Matakuliah}

Analisis hasil kinerja masing-masing dosen untuk semua kategori item kompetensi adalah (Tabel 5.2).

Tabel 5.2. Kinerja masing-masing Dosen JPMIPA FKIP UM-Mataram.

\begin{tabular}{clcc}
\hline No & \multicolumn{1}{c}{ Matakuliah } & $\begin{array}{c}\text { Persentasi kinerja } \\
\mathbf{( \% )}\end{array}$ & Kategori \\
\hline 1. & Fisika Matematika & 78,29 & Baik \\
2. & Fisika Radiasi & 71,57 & Baik \\
3. & Fisika Kuantum & 78,14 & Baik \\
4. & Sains Atmosfer & 74,57 & Baik \\
5. & Fisika Komputasi Lanjut & 70,14 & Baik \\
6. & Fisika Komputasi & 74,02 & Baik \\
7. & Pengantar Laboratorium & 73,48 & Baik \\
8. & Evaluasi Pembelajaran Fisika & 74,00 & Baik \\
9. & Fisika Modern & 75,58 & Baik \\
10. & Belajar dan Pembelajaran Mat. & 75,00 & Baik \\
11. & Matematika Diskrit & 48,29 & cukup \\
12. & Program Linier & 69,57 & Baik \\
13. & Kalkulus & 54,48 & cukup \\
\hline & Total & $\mathbf{9 1 7 , 1 3}$ & \\
\hline & Rata-rata & $\mathbf{7 0 , 5 5}$ & Baik \\
\hline
\end{tabular}

Tabel 5.4 menunjukkan bahwa secara umum kinerja setiap dosen dapat dikategorikan sudah baik, karena hanya dua dari tigabelas yang memperoleh kategori cukup. Dengan demikian kinerja dosen di jurusan PMIPA UM-Mataram dikatakan telah memenuhi standar pelayanan.

\subsection{Deskripsi Kinerja Dosen JPMIPA FKIP (2012-2013) berdasarkan masing-masing standar kompetensi.}

Tingkat kinerja keseluruhan dosen dalam cakupan kompetensi yang harus dilaksanakan sebagai tugas yang semestinya dapat dilihat dalam Tabel 5.3.

Tabel 5.3 Kinerja Dosen JPMIPA FKIP UM-Mataram tahun AK. 2012-2013.

\begin{tabular}{clcccc}
\hline $\boldsymbol{N}$ & $\begin{array}{c}\text { Jenis } \\
\text { Kompetensi }\end{array}$ & $\begin{array}{c}\text { Jumlah } \\
\text { item } \\
\text { pertanyaan }\end{array}$ & $\begin{array}{c}\text { Skor } \\
\text { maksimum }\end{array}$ & $\begin{array}{c}\text { Kategori } \\
(\mathbf{\% )}\end{array}$ & Keterangan \\
\hline 85 & $\begin{array}{l}\text { Kompetensi } \\
\text { Pedagogik }\end{array}$ & 7 & 140 & 77,92 & Baik \\
$\begin{array}{l}\text { Kompetensi } \\
\text { Profesional }\end{array}$ & 7 & & 77,61 & Baik \\
\hline
\end{tabular}




\begin{tabular}{lccc}
$\begin{array}{l}\text { Kompetensi } \\
\text { Kepribadian }\end{array}$ & 6 & 77,57 & Baik \\
$\begin{array}{l}\text { Kompetensi } \\
\text { Sosial }\end{array}$ & 5 & 77,04 & Baik \\
\hline & Total & $\mathbf{3 1 0 , 1 4}$ & \\
\hline & Rata-rata & $\mathbf{7 7 , 5 4}$ & Baik \\
\hline
\end{tabular}

Tabel 5.5 dan Gambar 5.1 menunjukkan bahwa secara umum kinerja setiap dosen JPMIPA FKIP pada standar kompetensi Pedagogik, Kompetensi Profesional, Kompetensi Kepribadian, dan Kompetensi Sosial dapat dikategorikan baik, masing-masing sebesar 77,92; 77,61; 77,57; dan 77,04. Dengan demikian kinerja dosen di jurusan PMIPA UM-Mataram tahun akademik 2012-2013 dikatakan telah memenuhi standar mutu pelayanan akademik.

\section{BAB VI \\ KESIMPULAN DAN SARAN}

\subsection{Kesimpulan}

Berdasarkan hasil analisis data, menunjukkan bahwa kinerja masingmasing dosen pengampu mata kuliah di jurusan PMIPA FKIP UM-Mataram pada tahun akademik 2012-2013 dalam standar kerja yang baik, dengan nilai rata-rata prosentase 70,55. Sedangkan secara umum kinerja dosen telah memenuhi empat aspek standar kompetensi dengan rata-rata 17,32 \%.

\subsection{Saran}

Untuk mendapatkan informasi yang lebih baik, jumlah responden diperbanyak agar kwalitas hasil penelitian lebih tinggi. Penilaian kinerja dosen harus dilakukan secara rutin baik oleh masing-masing prodi, jurusan, fakultas, maupun tingkat universitas, sehingga informasi dalam pengembangan sumber daya manusia di lingkungan civitas akademik dapat terus ditingkatkan. 


\section{DAFTAR PUSTAKA}

Arikunto, S. 2011. Dasar-Dasar Evaluasi Pendidikan. Jakarta: Bumi Aksara.

Armstrong, M. 1994. Manajemen Sumber Daya Manusia. Jakarta: Media Kompetindo.

As'ad, Mochammad. 2003. Psikologi Industri: Seri Sumber Daya Manusia. Yogyakarta: Liberty.

Bestira, I. 1998. Produktivitas Perusahaan. Bandung: Alumni.

Chairy, Liche Seniati. 2005. Avaluasi Dosen sebagai Bentuk Penilaian Kinerja. Disampaikan dalam Workshop Evaluasu kinerja Dosen Oleh Mahasiswa UIN Syarif \Hidayatullah. Jakarta.

Djakar, B. A. 2012. faktor-faktor yang mempengaruhi kinerja pegawai administrasi pada Universitas Muhammadiyah Mataram. Tesis, Program Pascasarjana Magister manajemen Sekolah Tinggi Ilmu Ekonomi Triatma Mulya Denpasar.

Dafidoft, Linda L. 1987. Introductions of Psychology. New Work: McGraw Hill Book Company.

Ermaya Suradinata. 1997. Pemimpin dan Kepemimpinan Pemerintahan. Jakarta: PT Gramedia Pustaka.

Giantri, dkk. 2008. Analisis Kepuasan Mahasiswa terhadap Proses BelajarMengajar di Program Diploma III FE UNUD. Buletin Studi Ekonomi. Vol. 13.No.1. 52-66.

Gibson, James L, John M.1, James H. Donnely. 1996. Organisasi, Perilaku, Struktur, Proses. Edisi Kedelapan. Jakarta: Bina Aksara.

Handoko, T. Hani. 2001. Manajemen Personalia dan Sumber Daya Manusia. Yogyakarta: BPFE.

Hasibuan, Muhammad. 2003. Manajemen Sumber Daya Manusia. Jakarta: Bumi Aksara.

Heidirachman dan Suad Husnan. 2002. Manajemen Personalia. Yogyakarta: BPFE.

Hamzah, dkk. 2010. Sistem Pendukung Kepuasan Penilaian Kinerja Dosen dengan Metode Balanced Scorecard (Studi Kasus: Universitas Respati Yogyakarta). Jurnal Informatika. Vol. 2. No. 1. 83-90.

Lane, Jan Erik. 1995. The Public Sectors, Concept, Model and Approaches. London: Sage Publications.

Martoyo, Susilo. 2000. Manajemen Sumber Daya Manusia. Yogyakarta: BPFE.

Panggabean, Mutiara S. 2002. Manajemen Sumber Daya Manusia. Jakarta: Ghalia Indonesia.

Robbins, Stephen P. 1997. Perilaku Organisasi. Jilid I dan II. Jakarta: Erlangga.

Disampaikan dalam seminar penelitian LEMLIT UM. Mataram / 2013. 
Riduwan dan Sunarto. 2010. Pengantar Statistika. Bandung: Alfabeta.

Sardiman. 2007. Interaksi dan Motivasi Belajar Mengajar. Jakarta: PT Raja Grafindo Persada.

Sugiyono. 2008. Metode Penelitian Administrasi. Bandung: Alfabeta.

Tim Manajemen. 2012. Buku Pedoman Universitas Muhammadiyah Mataram. Percetakan: Mataram.

Simamora, H. 2003. Manajemen Sumber Daya Manusia. Edisi Kedua. Yogyakarta: Bagian Penerbitan STIE YKPN.

Stonner, James AF, R. Edward Freeman, Daniel R. Gilbert JR. 1996. Manajemen. Jilid II. Jakarta: Prenhalindo.

Undang-undang nomor 14 Tahun 2005, tentang guru dan dosen.

Widoyoko, Eko Putro. 2012. Teknik Penyusunan Instrumen Penelitian. Yogyakarta: Pustaka Pelajar. 